\title{
Effects of inhibition of P2Y1 and P2Y12 on whole blood clotting, coagulum elasticity and fibrinolysis resistance studied with free oscillation rheometry
}

Sofia Ramström, Mats Rånby and Tomas Lindahl

Linköping University Post Print

N.B.: When citing this work, cite the original article.

Original Publication:

Sofia Ramström, Mats Rånby and Tomas Lindahl, Effects of inhibition of P2Y1 and P2Y12 on whole blood clotting, coagulum elasticity and fibrinolysis resistance studied with free oscillation rheometry, 2003, Thrombosis Research, (109), 5-6, 315-322. http://dx.doi.org/10.1016/S0049-3848(03)00254-8

Copyright: Elsevier http://www.elsevier.com/

Postprint available at: Linköping University Electronic Press http://urn.kb.se/resolve?urn=urn:nbn:se:liu:diva-25244 
Original article:

\section{Effects of inhibition of $\mathrm{P}_{1} \mathrm{Y}_{1}$ and $\mathrm{P} \mathrm{Y}_{12}$ on whole blood}

\section{clotting, coagulum elasticity and fibrinolysis resistance}

\section{studied with free oscillation rheometry}

Sofia Ramström ${ }^{1,2}$, Mats Rånby ${ }^{1,3}$ and Tomas L. Lindahl ${ }^{4}$

${ }^{1}$ Dept. of Biomedicine and Surgery, Div. of Clinical Chemistry, University Hospital, Linköping, Sweden; ${ }^{2}$ Forum Scientium Graduate School, Linköping University, Sweden; ${ }^{3}$ Global Hemostasis Institute MGR AB, Linköping, Sweden; ${ }^{4}$ Dept. of Clinical Chemistry, Laboratory Medicine, University Hospital, Linköping, Sweden.

Word count: 4177

Contact author: Sofia Ramström

Address: Dept. of Biomedicine and Surgery, Div. of Clinical Chemistry, University Hospital, SE-581 85 Linköping, Sweden

Telephone: +4613222425

Fax number: +46 13223240

E-mail: sofra@ifm.liu.se

Some of the data in this manuscript was presented as an oral presentation at the $2^{\text {nd }}$ International Meeting: The platelet ADP receptors, in S. Margherita di Pula, Italy, October 5, 2002. 


\section{Abstract}

Introduction: In vivo, initial platelet activation is likely caused by platelet contacts with collagen in the subendothelium or from the small amounts of thrombin formed by the tissue factor/factor VIIa complex. Our aim was to study the coagulative role of ADP released by the platelets after activation with strong stimuli such as collagen and/or thrombin, and the relative importance of the platelet $\mathrm{ADP}$ receptors $\mathrm{P} 2 \mathrm{Y}_{1}$ and $\mathrm{P} 2 \mathrm{Y}_{12}$.

Materials and Methods: We used $10 \mathrm{~Hz}$ free oscillation rheometry to measure clotting time, clot elasticity and fibrinolysis resistance of non-anticoagulated whole blood. The platelets were activated with a collagen-related peptide (CRP), with the PAR1 thrombin receptor activating peptide TRAP-6 or by thrombin, the latter generated by small amounts of thromboplastin. To inhibit the platelet ADP receptors, we used the $\mathrm{P} 2 \mathrm{Y}_{1}$ antagonist MRS2179 and the P2Y 12 antagonist AR-C69931MX.

Results: Both antagonists significantly retarded the clotting induced by CRP. The effects were most pronounced with AR-C69931MX. For TRAP-6, the same trend was seen, but the retardation was only significant with AR-C69931MX. Clotting induced by small amounts of thromboplastin was not affected by any ADP-receptor antagonist. Addition of both antagonists did not change the results as compared to samples with AR-C69931MX alone. Nor did the antagonists, one at a time or in concert, effect fibrinolysis or the elastic properties of the clot.

Conclusion: We conclude that ADP-receptor inhibition prolongs the clotting time for whole blood activated by CRP, but that it does not affect the properties of the subsequently formed coagulum. 
Keywords: haemostasis, platelet activation, platelet aggregation inhibitors, rheology, adenosine diphosphate, fibrinolysis

\section{Abbreviations}

\begin{tabular}{|c|c|}
\hline ADP, ATP, cAMP & $\begin{array}{l}\text { Adenosine diphosphate, adenosine triphosphate, cyclic adenosine } \\
\text { monophosphate }\end{array}$ \\
\hline AR-C69931MX & $\begin{array}{l}\text { Antagonist to the platelet } \mathrm{P} 2 \mathrm{Y}_{12} \text { receptor; } \mathrm{N}^{6} \text {-(2-methyl-tioethyl)- } \\
\text { 2-(3,3,3-trifluoropropylthio)- } \beta \text {, } \gamma \text {-dichloromethylene ATP }\end{array}$ \\
\hline CRP & $\begin{array}{l}\text { Collagen-related peptide, sequence } \mathrm{GCO}-(\mathrm{GPO})_{10}-\mathrm{GCOG}-\mathrm{NH}_{2} \text {, } \\
\text { where } \mathrm{O} \text { is hydroxyproline }\end{array}$ \\
\hline FOR & Free oscillation rheometer \\
\hline factor VIIa & Activated factor VII \\
\hline $\mathrm{G}^{\prime}$ & Elasticity modulus \\
\hline GPVI, GPIb & Glycoprotein VI, glycoprotein Ib \\
\hline MRS2179 & $\begin{array}{l}\text { Antagonist to the platelet } \mathrm{P}_{2} \mathrm{Y}_{1} \text { receptor; } \mathrm{N}^{6} \text {-methyl-2'- } \\
\text { deoxyadenosine-3',5'-bisphosphate }\end{array}$ \\
\hline PAR1 & Protease-activated receptor 1 \\
\hline $\mathrm{P}^{2} \mathrm{Y}_{1}$ & Platelet ADP receptor $\mathrm{P} 2 \mathrm{Y}_{1}$ \\
\hline $\mathrm{P}^{2} \mathrm{Y}_{12}$ & Platelet ADP receptor $\mathrm{P} 2 \mathrm{Y}_{12}$ \\
\hline TRAP-6 & Thrombin PAR1 receptor activating peptide, sequence SFLLRN \\
\hline
\end{tabular}




\section{Introduction}

ADP is an important platelet agonist present in erythrocytes and in platelet dense granules. It is considered to be a relatively weak agonist by itself, since the addition of ADP to platelets in vitro only causes shape change and a reversible aggregation if physiological levels of calcium are present in the medium. The dense granule content of ADP will be released as a response to stimulation by stronger platelet agonists such as thrombin or collagen and will amplify the effects by these strong agonists [1]. The platelet possesses several receptors involved in their response to ADP. The ADP receptor $\mathrm{P} 2 \mathrm{Y}_{1}$ is a G-protein-coupled receptor acting on $\mathrm{G \alpha}_{\mathrm{q}}$, leading to activation of phospholipase C. Activation via this receptor leads to a rise in intracellular calcium levels, shape change and a transient aggregation of the platelets [2]. The $\mathrm{P} 2 \mathrm{Y}_{1}$ receptor becomes refractory to repeated stimulation if the concentration of ADP remains high in the medium [3]. Transgenic mice without this receptor are viable and do not have spontaneous bleeding tendency, but show no platelet aggregation in response to ADP and an impaired aggregation in response to other agonists at low concentrations and to collagen at all concentrations. The $\mathrm{P}_{2} \mathrm{Y}_{1}$-deficient mice seem to have an increased resistance to thromboembolic events [4]. Inhibitors of this receptor include the stable adenosine analogues A2P5P, A3P5P, A3P5PS and the more efficient substances MRS2179 [5] and MRS2279 [1]. MRS2179 inhibits ADP-induced aggregation of human and rat platelets and prolongs the bleeding time in mice and rats [5]. Blockade of $\mathrm{P} 2 \mathrm{Y}_{1}$ is bypassed by stimulation of the $\mathrm{G} \alpha_{\mathrm{q}}$ pathway with serotonin [6]. Another G-protein-coupled ADP receptor, now denoted P2 $\mathrm{Y}_{12}$, was recently characterised [7] and cloned [8]. This receptor, previously denoted P2cyc, $\mathrm{P} 2 \mathrm{~T}_{\mathrm{AC}}, \mathrm{P}_{2 \mathrm{~T}}$, 
$\mathrm{P}_{2} \mathrm{Y}_{\mathrm{ADP}}$ or SP1999, acts via $\mathrm{G} \alpha_{\mathrm{i} 2}$ to inhibit the activity of adenylate cyclase, which suppresses the formation of cAMP so that activation can occur [1, 2, 9]. Activation of $\mathrm{P} 2 \mathrm{Y}_{12}$ is essential for sustained aggregation and potentiates secretion from activated platelets [1]. $\mathrm{P} 2 \mathrm{Y}_{12}$ is irreversibly inhibited in vivo by the thienopyridine drugs ticlopidine and clopidogrel [10]. Several competitive antagonists to $\mathrm{P}_{2} \mathrm{Y}_{12}$, also active in vitro, have been developed. These include AR-C66096MX, AR-C67085MX and ARC69931MX [1].

Platelet activation is not only important for the aggregation and secretion mechanisms forming the platelet plug, it is also a prerequisite for the formation of a proper surface for the assembly of the complexes of the plasma coagulation cascade. The role for the platelet surface in assembly of the tenase and prothrombinase complexes has long been known, but the platelets have also more recently been shown to support the activation of factor XI by thrombin [11]. The thrombin formed initially during coagulation cleaves fibrinogen to form the fibrin coagulum. Much larger amounts of thrombin are, however, formed after the point when the coagulum has been detected [12], implying that thrombin is even more important in modulating the coagulation process. The role of thrombin includes protection of the plug from removal by the fibrinolytic system via the activation of factor XIII [13] and a thrombin-activatable fibrinolysis inhibitor (TAFI) [14], and activation of the protein C anticoagulation pathway [15].

In vivo, initial platelet activation is likely caused by platelet contacts with collagen and von Willebrand factor in the subendothelium [16] or from the small amounts of thrombin formed when exposed tissue factor in the subendothelium forms a complex with factor VIIa and activates factor X [17]. The importance of ADP released from the platelet for coagulation after activation with these strong stimuli was the focus for this 
study. We have used a new technique called free oscillation rheometry (FOR) [18-20], which enables studies of processes and properties of coagulating whole blood clots. We have measured clotting time, clot elasticity and fibrinolysis resistance in nonanticoagulated, freshly drawn whole blood without any anticoagulant substance added (subsequently termed native blood). The platelets were activated via GPVI with a collagen-related peptide (CRP) [21], via protease-activated receptor 1 (PAR1) with a thrombin receptor agonist peptide, TRAP-6 [22], or via all thrombin receptors by the use of small amounts of thromboplastin. To inhibit the platelet ADP receptors, we used the $\mathrm{P}_{2} \mathrm{Y}_{1}$ antagonist MRS2179 and the $\mathrm{P}_{2} \mathrm{Y}_{12}$ antagonist AR-C69931MX. 


\section{Material and Methods}

Reagents

Phycoerythrin-conjugated mouse antibodies against GPIb (CD42b, clone AN51) were purchased from Dako AS (Glostrup, Denmark). The fluorescein (FITC)-conjugated chicken antibody towards human fibrinogen and the lysing solution were from Diapensia HB (Linköping, Sweden).

Chemicals for the HEPES buffer $(137 \mathrm{mmol} / \mathrm{L} \mathrm{NaCl}, 2.7 \mathrm{mmol} / \mathrm{L} \mathrm{KCl}, 1 \mathrm{mmol} / \mathrm{L}$ $\mathrm{MgCl}_{2}, 5.6 \mathrm{mmol} / \mathrm{L}$ glucose, $1 \mathrm{~g} / \mathrm{L}$ bovine serum albumin and $20 \mathrm{mmol} / \mathrm{L}$ HEPES (N[2-hydroxyethyl]piperazine-N'-[2-ethanesulfonic acid]), $\mathrm{pH}$ 7.40) and ADP (adenosine 5'-diphosphate monopotassium salt dihydrate) were from Sigma Chemical Company (St. Louis, MO, USA). The ADP powder was dissolved in distilled water to a concentration of $8.5 \mu \mathrm{mol} / \mathrm{L}$. The thrombin-receptor-agonist peptide TRAP-6 (SFLLRN) [22] was purchased from the Biotechnology Centre of Oslo, Oslo University, Norway and was dissolved in $0.9 \% \mathrm{NaCl}$ to $3.0 \mathrm{mg} / \mathrm{mL}$. A collagen-related peptide (CRP) with the sequence Gly-Cys-Hyp-(Gly-Pro-Hyp) ${ }_{10}-$ Gly-Cys-Hyp-Gly$\mathrm{NH}_{2}$ was kindly provided by Dr. Richard W. Farndale and Dr. Graham Knight, Cambridge, UK and crosslinked with SPDP (3-(2-pyridyldithio)propionic acid Nhydroxysuccinimide ester) according to their instructions [21]. The peptide solution was diluted to $35 \mu \mathrm{g} / \mathrm{mL}$ in $0.05 \%$ HAc. Freeze-dried rabbit brain thromboplastin (GHI 222) was from Global Hemostasis Institute, Linköping, Sweden. The powder was diluted in $0.9 \% \mathrm{NaCl}$ to a concentration of $0.3 \mathrm{AU} / \mathrm{mL}$ (where 1 arbitrary unit (AU) is equivalent to the amount of thromboplastin able to clot normal pooled plasma in 120 seconds). 
Recombinant human tissue-type plasminogen activator (alteplase, Actilyse ${ }^{\circledR}$ ) was from Boehringer Ingelheim GmbH (Ingelheim, Germany). It was diluted to $1 \mathrm{mg} / \mathrm{mL}$ in distilled water and thereafter to $15.5 \mu \mathrm{g} / \mathrm{mL}$ (9000 IU/mL) in $0.9 \% \mathrm{NaCl}$. Recombinant hirudin (lepirudin, Refludan ${ }^{\circledR}$ ) was from Aventis (Strasbourg, France).

MRS2179 ( $\mathrm{N}^{6}$-methyl-2'-deoxyadenosine-3',5'-bisphosphate) (tetraammonium salt) was from Tocris Cookson Ltd (Bristol, UK), and was dissolved in distilled water to a concentration of $10 \mathrm{mmol} / \mathrm{L}$. AR-C69931MX (N ${ }^{6}$-(2-methyl-tioethyl)-2-(3,3,3trifluoropropylthio)- $\beta$, $\gamma$-dichloromethylene ATP) (tetrasodium salt) was kindly provided by AstraZeneca (Dr. Michael Wayne, Wilmington, DE, USA). It was dissolved in $0.9 \% \mathrm{NaCl}$ to a concentration of $10 \mathrm{mmol} / \mathrm{L}$.

The antibodies and the thromboplastin were kept at $+8^{\circ} \mathrm{C}$. All other solutions were kept at $-70^{\circ} \mathrm{C}$ until the time of use.

\section{Blood sampling}

Venous blood was collected with minimum trauma and stasis via a 21-gauge needle $(0.8 \times 40 \mathrm{~mm})$ in $4.5 \mathrm{~mL}$ plastic vacuum tubes $\left(\mathrm{S}-\right.$ Monovette ${ }^{\circledR}$, Sarstedt, Nümbrecht, Germany). Sterile empty tubes were used for native blood experiments. For flow cytometry experiments, $500 \mu \mathrm{L}$ of recombinant hirudin (2000 ATU/mL) was added to the tubes before blood collection, yielding a final concentration of $200 \mathrm{ATU} / \mathrm{mL}$. All blood donors gave informed consent to blood sampling. The blood collection protocol was approved by the Ethics Committee at Linköping University Hospital.

The blood donors were apparently healthy individuals, which had not ingested any drugs known to interfere with platelet function and without reported bleeding problems. Blood was also collected from a patient with a moderate bleeding tendency, which was 
previously shown to have a severely impaired release of dense granule contents (patient 1 , characterized in [23]).

\section{Flow cytometry}

Flow cytometry was performed on an Ortho Cytoron Absolute Flow Cytometer with the software ImmunoCount II (v. 2.00) (Ortho, Raritan, NY, USA).

Platelet activation was measured as platelet-bound fibrinogen according to a method described elsewhere $[24,25]$. In brief, $10 \mu \mathrm{L}$ of well mixed whole blood, anticoagulated with hirudin, was transferred to plastic tubes containing MRS2179 or AR-C69931MX, FITC-conjugated antibody against human fibrinogen (final concentration $2 \mu \mathrm{g} / \mathrm{mL}$ ), mouse anti-GPIb-phycoerythrin antibody (final concentration $1.8 \mu \mathrm{g} / \mathrm{mL}$ ) for identification of the platelets and HEPES buffer to a final volume of $90 \mu \mathrm{L}$. After 10 minutes, $10 \mu \mathrm{L}$ of ADP, CRP or buffer was added to the samples at exact time intervals. Final concentrations were $0.85 \mu \mathrm{mol} / \mathrm{L}$ of ADP and $3.5 \mu \mathrm{g} / \mathrm{mL}$ of CRP. After exactly 10 minutes, the reaction was stopped by the addition of $1000 \mu \mathrm{L}$ of lysing solution. The samples were left for 10 minutes to lyse the erythrocytes, and were thereafter diluted 1:20 in lysing solution before analysis on the flow cytometer. All steps were performed at room temperature and without stirring the samples. A discrimination frame was set around the platelet cluster using forward light scatter and FL2 (GPIb-phycoerythrin). An analytical cut-off was pre-set in the FL1 fluorescence channel (FITC) in order to divide the particles within the discrimination frame in samples with a non-binding antibody with corresponding fluorescence intensity into two fractions, one that contained $98.5-99.5 \%$ of the platelets and the other containing the brightest $0.5-1.5 \%$ of 
the platelets. Platelets with fluorescence intensity higher than the cut-off were identified as fibrinogen binding cells [25]. All samples were run in duplicate.

\section{FOR experiments}

Four-channel $10 \mathrm{~Hz}$ free oscillation rheometers (FOR), ReoRox ${ }^{\circledR} 4$ [18, 26], disposable polypropylene sample cups, gold-plated reaction chambers for elasticity measurements and software (ReoRox ${ }^{\circledR} 4$ v. 2.00 and ReoRox ${ }^{\circledR} 4$ Viewer v. $2.11 \mathrm{k}$ ) were from GHI (Global Hemostasis Institute MGR AB), Linköping, Sweden. In this rheometer, oscillation is initiated by a forced turn of the sample cup every 2.5 seconds. After a brief hold time, the sample cup is released, allowing rotational oscillation with very low friction around the longitudinal axis. An optic angular sensor records the frequency $(\mathrm{Fq})$ and damping (D) of the oscillation as a function of time. This is plotted as a curve, from which the time for different curve features may be determined. This instrument may be used in a "surface load" mode, with blood added to a single cup. A typical tracing of coagulation of native blood and subsequent fibrinolysis of the coagulum is shown in Figure 1. To allow determination of coagulum elasticity, gold-plated reaction chambers were used. The reaction chamber included a cylindrical sample cup (12 $\mathrm{mm}$ in diameter) and an inner cylinder, a bob (6 $\mathrm{mm}$ in diameter), attached to a hollow shaft and immersed from above into the centre of the sample cup. With the bob in a fixed position, the structure of the fibrin fibres coupling the cup to the bob, and the amount and activity of platelets bound to the fibrin network, will affect the frequency and damping of the sample cup oscillation. The gold coating enables measurements in whole blood, since fibrinogen binds firmly to the gold surface and does not detach as the platelets start to retract the clot. A typical curve for coagulating whole blood with a 
bob present is shown in Figure 2. In this mode, called "gap load", i.e. when the wavelength of the oscillating wave is larger than the distance between the cup and the bob, algorithms in the ReoRox ${ }^{\circledR} 4$ Viewer program may be used to calculate the elasticity modulus $\left(G^{\prime}\right)$ from the frequency and damping data.

Clot detection in the present study was based on Pythagorean summation of changes in $\mathrm{Fq}$ and $\mathrm{D}$, reaching a predefined level C:

$\sqrt{ }\left(\Delta \mathrm{Fq}^{2}+\Delta \mathrm{D}^{2}\right) \geq \mathrm{C}$

The "high sensitivity state detector" (where $\mathrm{C}=0.01$ ) was used here, and the related endpoint is referred to as "clotting time". We have shown that this detector gives results close to the manual reference method of visual clot detection $\left(r^{2}=0.97\right.$, submitted for publication). To determine the fibrinolysis start point, the state detector function was used again but starting at 10 minutes after the frequency minimum time (where a steady state with a firm clot was found). The fibrinolysis end point, when both the damping and frequency had returned to their original levels, was found by letting the state detector find the last point where the change was large enough to trigger the detector (see Figure 1). For evaluation of the FOR curves from the elasticity measurements, the elasticity modulus $\left(\mathrm{G}^{\prime}\right)$ was plotted in the ReoRox ${ }^{\circledR} 4$ Viewer software according to the manufacturers instructions. From this curve, the maximal G' value (G'max), the time between clotting time and G'max ("time to G'max") and the slope of the G' curve at 300 $\mathrm{Pa}$ ("G' slope at $300 \mathrm{~Pa}$ ) were determined. These parameters have been used to evaluate G' data in previous studies [27]. The clotting times were also determined from the original curves with the same detector as for the fibrinolysis measurements. 
Native blood was pooled in a plastic tube and without delay added to tubes containing MRS2179, AR-C69931MX, a combination of both substances, or the same volume of $0.9 \% \mathrm{NaCl}$. Final concentrations were $0.2 \mathrm{mmol} / \mathrm{L}$ for MRS2179 and $0.1 \mathrm{mmol} / \mathrm{L}$ for AR-C69931MX. The concentrations of AR-C699331MX and MRS2179 for the FOR experiments were chosen after performing the flow cytometry experiments as the concentration ten times higher than the one giving maximal inhibition of both ADP- and CRP-induced fibrinogen binding. The ten-fold increase was to assure complete inhibition even though the blood was used undiluted for the FOR experiments, while it was diluted 1:10 for flow cytometry. The blood was incubated for five minutes and then mixed with rt-PA (final concentration $180 \mathrm{IU} / \mathrm{mL}$ ) and CRP, TRAP-6 or thromboplastin (final concentrations $0.35 \mu \mathrm{g} / \mathrm{mL}, 75 \mu \mathrm{g} / \mathrm{mL}$ and $0.01 \mathrm{AU} / \mathrm{mL}$, respectively) in polypropylene sample cups before these were placed in the FOR. The final volume was $500 \mu \mathrm{L}$.

\section{Elasticity measurements}

For the elasticity measurements, gold-plated reaction chambers were used.

The reaction chamber was placed in the FOR before blood sampling. Native blood was collected and incubated with MRS2179 or AR-C69931MX as stated for the fibrinolysis experiments. $1 \mathrm{~mL}$ was then withdrawn with a $1 \mathrm{~mL}$ disposable plastic syringe, mixed with CRP (final concentration $0.35 \mu \mathrm{g} / \mathrm{mL}$ ) and added to the FOR cup through the hollow shaft of the bob.

Elasticity measurements were also performed on blood from a patient with a platelet defect affecting dense granule release, as well as on healthy volunteers $(n=8)$, using a higher concentration of CRP $(1.75 \mu \mathrm{g} / \mathrm{mL})$ and without the pre-incubation step used for the inhibitor experiments. 
For all blood donors, a control, consisting of blood with only buffer added, was also analysed. If the control showed clotting times less than 20 minutes, the whole experiment was discarded because of artefactual coagulation activation caused by the blood sampling procedure.

\section{Statistics}

Data analysis was performed using SPSS for Windows (SPSS Inc, Chicago, IL, USA). Comparisons between groups were made with the non-parametric Wilcoxon Matched Pairs test. 


\section{Results}

\section{Flow cytometry}

At final concentrations of $0.01 \mu \mathrm{mol} / \mathrm{L}$ AR-C69931MX or $10 \mu \mathrm{mol} / \mathrm{L} \mathrm{MRS} 2179$, complete inhibition of ADP induced fibrinogen binding was observed (Figure 3). For CRP-induced fibrinogen binding, where approximately $65 \%$ of the platelets bound fibrinogen in the absence of inhibitor, AR-C69931MX showed maximal effect in doses above $0.1 \mu \mathrm{mol} / \mathrm{L}$, where the percentage platelets binding fibrinogen had decreased to approximately $15 \%$. MRS2179 was less effective, regardless of concentration there were still approximately 30\% fibrinogen-binding platelets present (Figure 4). Each point in Figures 3 and 4 shows the mean and SD for 3-5 individuals (except for $10^{-3} \mathrm{~mol} / \mathrm{L}$ MRS2179, which is a single determination). Similar results were found in samples anticoagulated with citrate, although the percentage of fibrinogen-positive platelets was consistently higher (data not shown).

\section{Clotting times and fibrinolysis resistance}

Figure 5 shows the results from the clotting and fibrinolysis experiments. The CRPinduced clotting was significantly retarded $(\mathrm{p}<0.05)$ by both inhibitors. The largest effects were seen with AR-C69931MX. TRAP-6-induced clotting showed a similar pattern, but the retardation was only significant with AR-C69931MX. Thromboplastininduced clotting was not retarded with any ADP-receptor antagonist. Addition of both AR-C69931MX and MRS2179 to the same sample did not prolong the times any further, as compared to the samples with AR-C69931MX alone (n=3, data not shown). 
For time between clotting and start of fibrinolysis, no significant differences were seen for any of the combinations. The same was true for the length of the fibrinolysis period (time between fibrinolysis start and end points).

\section{Elasticity measurements}

Using gold-plated reaction chambers, the elasticity development was examined in whole blood samples with CRP added alone or in the presence of MRS2179 and/or ARC69931MX. The results are shown in Table 1. Due to the inter-individual variation, the results were plotted as normalised values, which are shown in Figure 6. Once again, the clotting time was the only parameter that was significantly changed by the addition of MRS2179 and AR-C69931MX ( $\mathrm{p}<0.05)$. Addition of both antagonists did not change the results as compared to samples with AR-C69931MX alone (n=3, data not shown). The results from the examination of the patient with decreased dense granule release capacity are shown in Table 2 . This patient shows a pronounced prolongation in clotting time (>2 SD longer than the normal population), but no other parameters were outside the reference interval for the normal individuals. 


\section{Discussion}

The fact that ADP is important for aggregation and calcium influx in the activated platelet is well known and has been studied for a long time. The antithrombotic effects of drugs blocking $\mathrm{P} 2 \mathrm{Y}_{12}$ are also well established [10]. Our flow cytometric results clearly showed that ADP release from the platelets is an important part of the response to stronger stimuli such as the collagen-related peptide. This peptide has been shown to increase intracellular calcium levels, activate protein kinase $\mathrm{C}$ and phosphorylate phospholipase $\mathrm{C} \gamma 2$ even in the presence of apyrase in the medium, but it could not decrease the adenylate cyclase activity [28]. This could explain why blocking the $\mathrm{P} 2 \mathrm{Y}_{12}$ receptor was more effective in inhibiting platelet fibrinogen binding after CRP stimulation.

In the FOR studies, however, ADP-receptor inhibition only affected the early phase of the coagulation process. Prolonged clotting times were seen for both antagonists, even though the effects were larger for the $\mathrm{P}_{2} \mathrm{Y}_{12}$ antagonist AR-C69931MX. The combination of both antagonists did not prolong the clotting time more than ARC69931MX alone. $\mathrm{P}_{2} \mathrm{Y}_{1}$ has been reported to be important in the early phases of collagen-induced platelet aggregation, prolonging the lag phase in the aggregation curve, while it only affected aggregation in response to thrombin at sub-threshold concentrations [4]. This could explain the prolongation of the clotting times seen with MRS2179 in the samples with the collagen-related peptide (CRP) added. $\mathrm{P}_{2} \mathrm{Y}_{1}$ receptor blockade may be bypassed by stimulating the $\mathrm{G} \alpha_{\mathrm{q}}$ pathway with serotonin [6]. Serotonin is present in platelet dense granules, and is released in response to strong platelet stimuli such as CRP or thrombin. It is therefore probable that serotonin 
was released and could diminish the effect of $\mathrm{P}_{2} \mathrm{Y}_{1}$ receptor inhibition, but this is also the situation probably found in vivo, where a number of different activator substances are likely to act on a single platelet. This could also be an explanation of the more pronounced clotting time prolongation seen in the patient with a defective dense granule release, since this should result in a defective release of not only ADP but also serotonin.

The $\mathrm{P}_{2} \mathrm{Y}_{12}$ receptor has been reported to be involved in all cases where ADP acts as a co-stimulus to other agonists [1]. It has a potentiating effect on platelet secretion, and is also involved in aggregate stabilisation and in full activation of the platelet fibrinogen receptor, $\alpha \mathrm{IIb} \beta 3$ integrin (GPIIb/IIIa) [1]. The prolonged clotting times seen when $\mathrm{P}^{2} \mathrm{Y}_{12}$ was inhibited illustrate its importance in the early phase of coagulation when CRP or TRAP-6 was used to activate the platelets.

However, even though both $\mathrm{P} 2 \mathrm{Y}_{1}$ and $\mathrm{P} 2 \mathrm{Y}_{12}$ antagonists could prolong the clotting times of the whole blood samples, they could neither affect the properties of the coagulum formed, nor the fibrinolysis resistance. Thus, the large amounts of thrombin formed later in the coagulation process seem to be able to overcome the effects of blocking the ADP receptor pathways. This is partly in line with a recent abstract showing that $\mathrm{P}_{2} \mathrm{Y}_{12}$ inhibition delayed the onset of thrombin generation in platelet-rich plasma, but not the total amount of thrombin formed [29]. Inhibition of $\mathrm{P}_{2} \mathrm{Y}_{1}$ was reported not to affect the thrombin generation curve at all. In that study, thromboplastin was used to initiate thrombin formation. In our experiments, thromboplastin activated blood samples were not affected by any of the ADP-receptor antagonists. The reason for this could be that we used a higher concentration of thromboplastin, yielding a clotting time of approximately 10 minutes, as compared to the 25-minute lag phase of thrombin 
generation reported in the other study [29]. With TRAP-6, however, we saw a clear effect when $\mathrm{P} 2 \mathrm{Y}_{12}$ was inhibited. This confirms previous reports that activation of PAR1 alone is not enough to trigger a full response in the platelet in the presence of apyrase [30] or a $\mathrm{P} 2 \mathrm{Y}_{12}$ antagonist [31]. In contrast, both these studies showed that thrombin could induce a full response in platelets even in the absence of ADP. The fact that at least P2 $\mathrm{Y}_{12}$ inhibitors have proven to be effective antithrombotic drugs illustrates the importance of the initial phase of platelet activation and blood coagulation for the subsequent formation of an occlusive thrombus. The lack of effect in later stages of coagulation could even be an advantage, i.e. a possibly better safety profile for the treatment. Increasing knowledge of the role of different receptors in the formation and properties of a coagulum is important for our understanding of the role of the platelet in blood coagulation.

\section{Acknowledgements}

This study was supported by the Swedish Society of Medicine and the County Council of Östergötland. Sofia Ramström acknowledges partial salary support from Forum Scientium Graduate School, Linköping University, which is supported by grants from the Swedish Foundation for Strategic Research (SSF). The authors also thank all the blood donors and the staffs of the Department of Clinical Chemistry, University Hospital, Linköping, and Global Hemostasis Institute, Linköping, Sweden for their support. 


\section{References}

1. Gachet C. ADP receptors of platelets and their inhibition. Thromb Haemost 2001; 86: 222-32.

2. Woulfe D, Yang J, and Brass L. ADP and platelets: the end of the beginning. J Clin Invest 2001; 107: 1503-5.

3. Baurand A, Eckly A, Bari N, Leon C, Hechler B, Cazenave JP, and Gachet C. Desensitization of the platelet aggregation response to ADP: differential downregulation of the P2Y1 and P2cyc receptors. Thromb Haemost 2000; 84: 484-91.

4. Leon C, Hechler B, Freund M, Eckly A, Vial C, Ohlmann P, Dierich A, LeMeur M, Cazenave JP, and Gachet C. Defective platelet aggregation and increased resistance to thrombosis in purinergic P2Y(1) receptor-null mice. J Clin Invest 1999; 104: 1731-7. 5. Baurand A, Raboisson P, Freund M, Leon C, Cazenave JP, Bourguignon JJ, and Gachet C. Inhibition of platelet function by administration of MRS2179, a P2Y1 receptor antagonist. Eur J Pharmacol 2001; 412: 213-21.

6. Jin J and Kunapuli SP. Coactivation of two different G protein-coupled receptors is essential for ADP-induced platelet aggregation. Proc Natl Acad Sci USA 1998; 95: 8070-4.

7. Foster CJ, Prosser DM, Agans JM, Zhai Y, Smith MD, Lachowicz JE, Zhang FL, Gustafson E, Monsma FJ, Jr., Wiekowski MT, Abbondanzo SJ, Cook DN, Bayne ML, Lira SA, and Chintala MS. Molecular identification and characterization of the platelet ADP receptor targeted by thienopyridine antithrombotic drugs. J Clin Invest 2001; 107: 1591-8. 
8. Hollopeter G, Jantzen HM, Vincent D, Li G, England L, Ramakrishnan V, Yang RB, Nurden P, Nurden A, Julius D, and Conley PB. Identification of the platelet ADP receptor targeted by antithrombotic drugs. Nature 2001; 409: 202-7.

9. Storey RF, Sanderson HM, White AE, May JA, Cameron KE, and Heptinstall S. The central role of the $\mathrm{P}(2 \mathrm{~T})$ receptor in amplification of human platelet activation, aggregation, secretion and procoagulant activity. Br J Haematol 2000; 110: 925-34. 10. Clutton P, Folts JD, and Freedman JE. Pharmacological control of platelet function. Pharmacol Res 2001; 44: 255-64.

11. Oliver JA, Monroe DM, Roberts HR, and Hoffman M. Thrombin activates factor XI on activated platelets in the absence of factor XII. Arterioscler Thromb Vasc Biol 1999; 19: 170-7.

12. Rand M, Lock J, van't Veer C, Gaffney D, and Mann K. Blood clotting in minimally altered whole blood. Blood 1996; 88: 3432-45.

13. Muszbek L, Adany R, and Mikkola H. Novel aspects of blood coagulation factor XIII. I. Structure, distribution, activation, and function. Crit Rev Clin Lab Sci 1996; 33: $357-421$.

14. Bajzar L, Manuel R, and Nesheim ME. Purification and characterization of TAFI, a thrombin-activable fibrinolysis inhibitor. J Biol Chem 1995; 270: 14477-84.

15. Esmon CT. Thrombomodulin as a model of molecular mechanisms that modulate protease specificity and function at the vessel surface. FASEB J 1995; 9: 94655.

16. Kehrel B. Platelet-collagen interactions. Semin Thromb Hemost 1995; 21: 1239. 
17. Hoffman M and Monroe DMI. A cell-based model of hemostasis. Thromb Haemost 2001; 85: 958-65.

18. Bohlin L, Method of measuring rheological properties and rheometer for carrying out the method, in PCT (Patent Cooperation Treaty) publication number WO94/08222. 1994.

19. Hansson K, Tengvall P, Lundström I, Rånby M, and Lindahl T. Surface plasmon resonance and free oscillation rheometry in combination: A new approach for studies on haemostasis and biomaterials. Biosens Bioelectron 2002; 17: 747-59.

20. Ramström S, Rånby M, and Lindahl T. The role of platelets in blood coagulation - effects of platelet agonists and of GPIIb/IIIa inhibitors studied by free oscillation rheometry. Thromb Res 2002; 105: 165-72.

21. Morton LF, Hargreaves PG, Farndale RW, Young RD, and Barnes MJ. Integrin alpha 2 beta 1-independent activation of platelets by simple collagen-like peptides: collagen tertiary (triple-helical) and quaternary (polymeric) structures are sufficient alone for alpha 2 beta 1-independent platelet reactivity. Biochem J 1995; 306: 337-44. 22. Hui KY, Jakubowski JA, Wyss VL, and Angleton EL. Minimal sequence requirement of thrombin receptor agonist peptide. Biochem Biophys Res Commun 1992; 184: 790-6.

23. Ramström A, Fagerberg I, and Lindahl T. A flow cytometric assay for the study of dense granule storage and release in human platelets. Platelets 1999; 10: 153-8. 24. Lundahl T, Petersson J, Fagerberg I, Berg S, Larsson A, and Lindahl T. Impaired platelet function correlates with multi-organ dysfunction. A study of patients with sepsis. Platelets 1998; 9: 223-5. 
25. Lindahl TL, Festin R, and Larsson A. Studies of fibrinogen binding to platelets by flow cytometry: an improved method for studies of platelet activation. Thromb Haemost 1992; 68: 221-5.

26. Bohlin L, Bearing device, in PCT (Patent Cooperation Treaty) publication number WO98/54475. 1998.

27. Ramström S, Rånby $\mathrm{M}$, and Lindahl T. Effects of abciximab on coagulum elasticity measured with free oscillation rheometry. Platelets 2002; 13: 355-6 (abstract).

28. Barnes MJ, Knight CG, and Farndale RW. The use of collagen-based model peptides to investigate platelet-reactive sequences in collagen. Biopolymers 1996; 40: 383-97.

29. Leon C, Ravanat C, Freund M, Cazenave J, and Gachet C. Differential involvement of the $\mathrm{P} 2 \mathrm{Y}_{1}$ and $\mathrm{P} 2 \mathrm{Y}_{12}$ receptors in platelet-mediated aspects of coagulation. Haematologica 2002; 87:(10, Suppl I) p. 20 (abstract).

30. Lau LF, Pumiglia K, Cote YP, and Feinstein MB. Thrombin-receptor agonist peptides, in contrast to thrombin itself, are not full agonists for activation and signal transduction in human platelets in the absence of platelet-derived secondary mediators. Biochem J 1994; 303: 391-400.

31. Kim S, Foster C, Lecchi A, Quinton TM, Prosser DM, Jin J, Cattaneo M, and Kunapuli SP. Protease-activated receptors 1 and 4 do not stimulate G(i) signaling pathways in the absence of secreted ADP and cause human platelet aggregation independently of G(i) signaling. Blood 2002; 99: 3629-36. 
Table 1

\begin{tabular}{|l|c|c|c|}
\hline Parameter & $\begin{array}{c}\text { CRP only } \\
(\mathbf{0 . 3 5} \mu \mathbf{g} / \mathbf{m L})\end{array}$ & $\begin{array}{c}\text { CRP + } \\
\text { MRS2179 } \\
(\mathbf{2 0 0} \boldsymbol{\mu m o l} / \mathbf{L})\end{array}$ & $\begin{array}{c}\text { CRP + } \\
\text { AR-C69931 MX } \\
(\mathbf{1 0 0} \boldsymbol{\mu m o l} / \mathbf{L})\end{array}$ \\
\hline Clotting time (min) & $11.4 \pm 2.0$ & $12.7 \pm 1.7$ & $13.4 \pm 2.1$ \\
\hline G'max (Pa) & $984 \pm 91$ & $941 \pm 163$ & $925 \pm 54$ \\
\hline Time to G'max (min) & $49.6 \pm 6.5$ & $50.6 \pm 4.8$ & $52.6 \pm 10.8$ \\
\hline $\begin{array}{l}\text { G' slope at 300 Pa } \\
\text { (Pa/min) }\end{array}$ & $55 \pm 9$ & $50 \pm 11$ & $51 \pm 10$ \\
\hline
\end{tabular}


Table 2

\begin{tabular}{|l|c|c|}
\hline Parameter & $\begin{array}{c}\text { Normal blood donors } \\
(\mathbf{n}=\mathbf{8})\end{array}$ & Patient 1 \\
\hline Clotting time (min) & $10.2 \pm 2.0$ & 17.1 \\
\hline G'max (Pa) & $961 \pm 187$ & 795 \\
\hline Time to G'max (min) & $57.6 \pm 13.1$ & 73.9 \\
\hline $\begin{array}{l}\text { G' slope at 300 Pa } \\
\text { (Pa/min) }\end{array}$ & $45 \pm 18$ & 29 \\
\hline
\end{tabular}




\section{Table legends}

Table 1: Clotting time and elasticity modulus $\left(\mathrm{G}^{\prime}\right)$ parameters for native whole blood samples incubated with MRS2179 or AR-C69931MX before addition of a collagenrelated peptide (CRP), analysed in the ReoRox ${ }^{\circledR} 4$ FOR with gold-plated cup and bob. The values are mean \pm SD for 6 individuals.

Table 2: Clotting time and elasticity modulus $\left(\mathrm{G}^{\prime}\right)$ parameters for native whole blood samples mixed with a collagen-related peptide (CRP, final concentration $1.75 \mu \mathrm{g} / \mathrm{mL}$ ) and analysed in the ReoRox ${ }^{\circledR} 4$ FOR with gold-plated cup and bob. The table shows mean \pm SD for 8 healthy individuals and the results from a patient with defective secretion from dense granules. 


\section{Figure legends}

Figure 1. A typical curve from the ReoRox ${ }^{\circledR} 4$ FOR instrument where a native whole blood sample is added to a rheometer cup containing a collagen-related peptide (CRP, $0.35 \mu \mathrm{g} / \mathrm{mL})$ and a small amount of t-PA (180 IU $/ \mathrm{mL})$. The black circles show the shift in frequency, while the open grey circles show the shift in logarithmic damping. The coagulation process is here followed by fibrinolysis dissolving the coagulum.

Figure 2. A typical curve from the ReoRox ${ }^{\circledR} 4$ FOR instrument where a native whole blood sample is mixed with a collagen-related peptide (CRP, $0.35 \mu \mathrm{g} / \mathrm{mL})$ and added to a gold-plated rheometer cup with a gold-plated bob immersed in the center. The black circles show the shift in frequency, while the open grey circles show the shift in logarithmic damping. The coagulation process will create fibrin fibers coupling the cup wall to the bob, resulting in an increased frequency and damping of the oscillation as the elasticity of the coagulum rises.

Figure 3. Percentage of platelets binding fibrinogen after addition of ADP ( 0.85 $\mu \mathrm{mol} / \mathrm{L}$ ) to hirudinised blood in the presence of different concentrations of the ADP receptor antagonists MRS2179 and AR-C69931MX, as measured by flow cytometry.

Figure 4. Percentage of platelets binding fibrinogen after addition of a collagen-related peptide (CRP, $3.5 \mu \mathrm{g} / \mathrm{mL}$ ) to hirudinised blood in the presence of different concentrations of the ADP receptor antagonists MRS2179 and AR-C69931MX, as measured by flow cytometry. 
Figure 5. Clotting time, time between clotting time and fibrinolysis start point, and time between fibrinolysis start and end points, for native whole blood samples incubated with MRS2179 or AR-C69931MX before the addition of a collagen-related peptide (CRP, $0.35 \mu \mathrm{g} / \mathrm{mL})$, TRAP-6 $(15 \mu \mathrm{g} / \mathrm{mL})$ or thromboplastin $(0.01 \mathrm{AU} / \mathrm{mL})$ together with rt-PA (final concentration $180 \mathrm{IU} / \mathrm{mL}$ ). $* \mathrm{p}<0.05$ when compared to the result for agonist alone in the same donor.

Figure 6. Normalised data for clotting time and elasticity modulus $\left(\mathrm{G}^{\prime}\right)$ parameters for native whole blood samples incubated with MRS2179 or AR-C69931MX before addition of a collagen-related peptide (CRP, $0.35 \mu \mathrm{g} / \mathrm{mL}$ ), analysed in the ReoRox ${ }^{\circledR} 4$ FOR with gold-plated cup and bob. $* \mathrm{p}<0.05$ when compared to the result for agonist alone in the same donor. 
Figure 1:

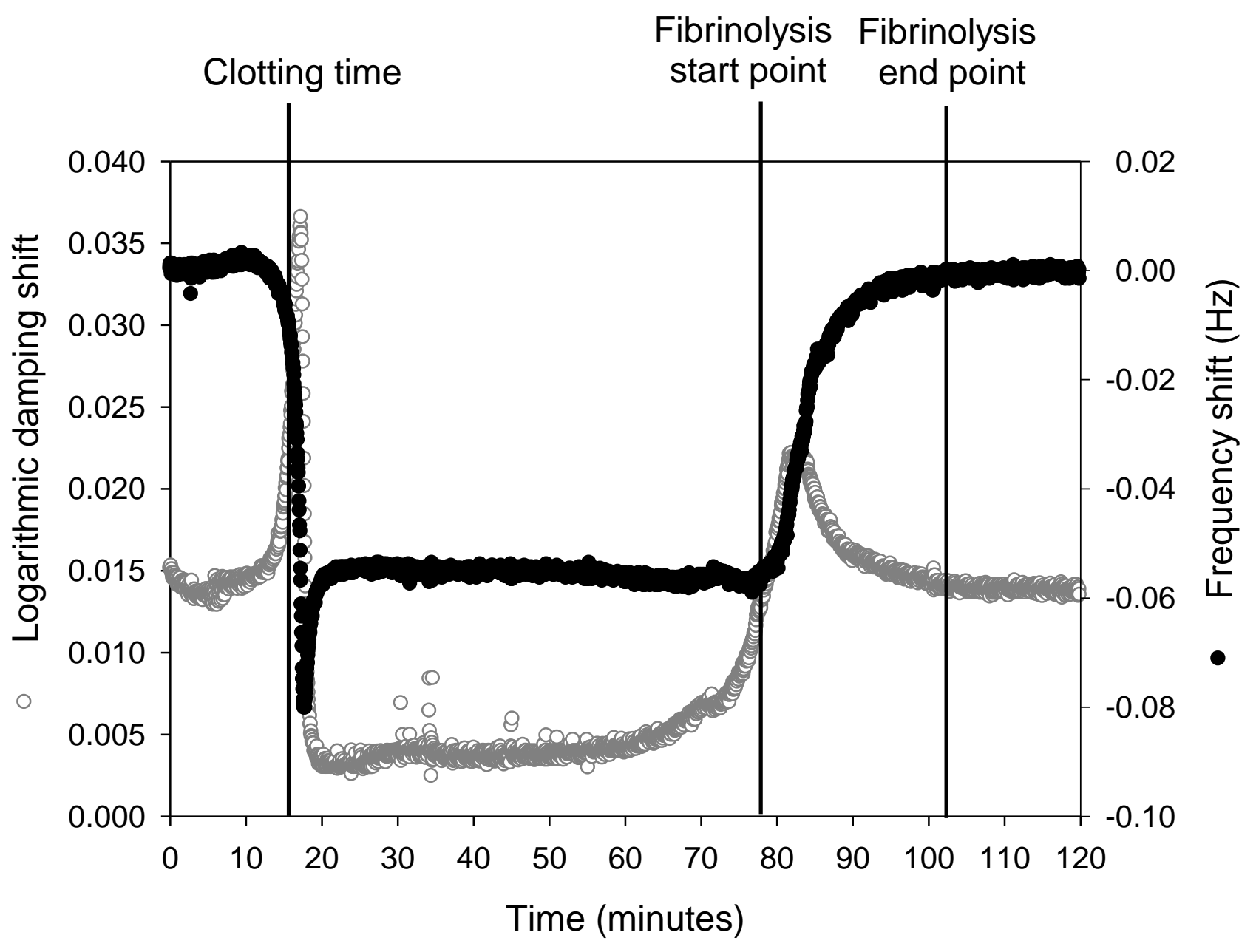


Figure 2:

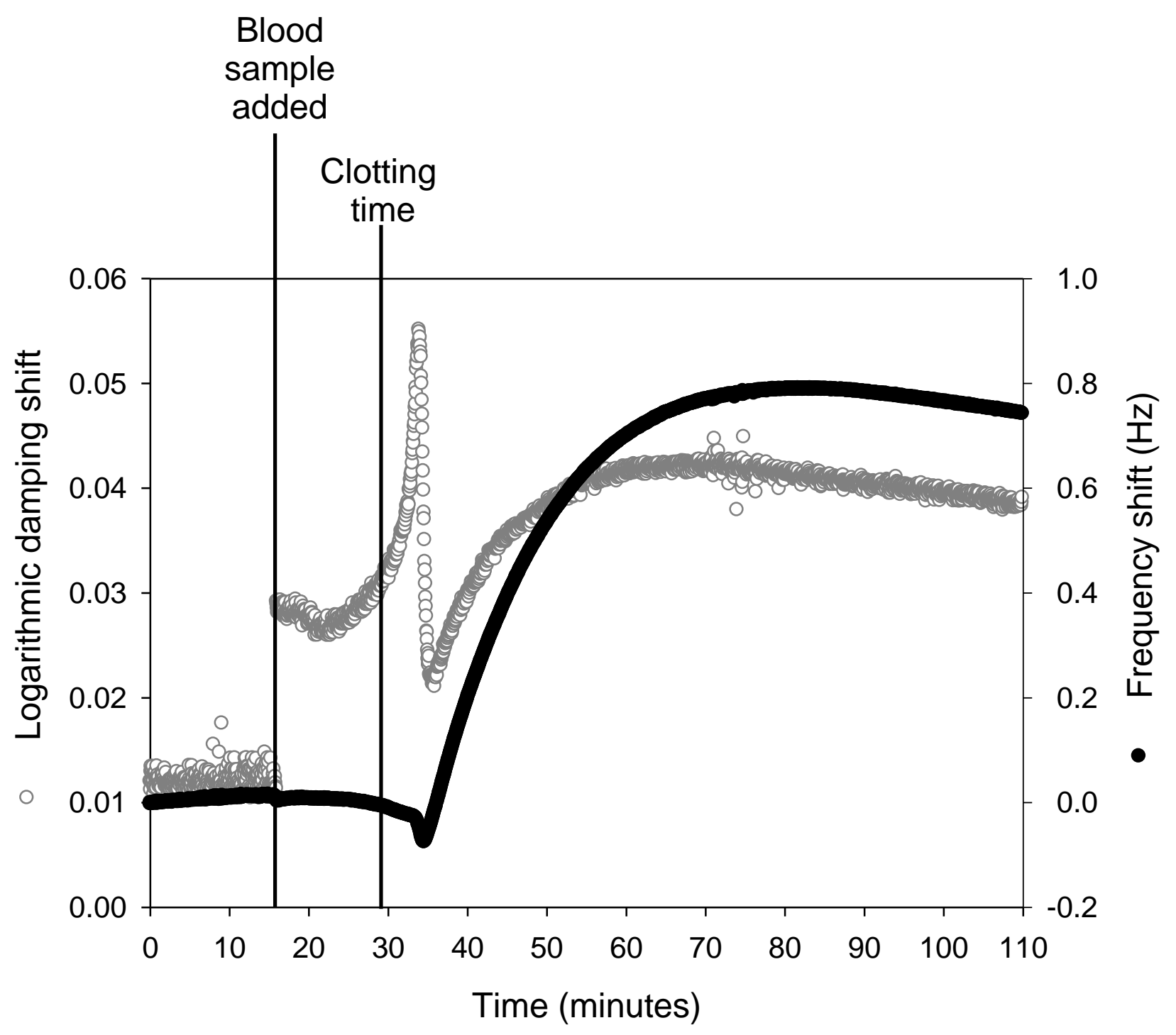


Figure 3:

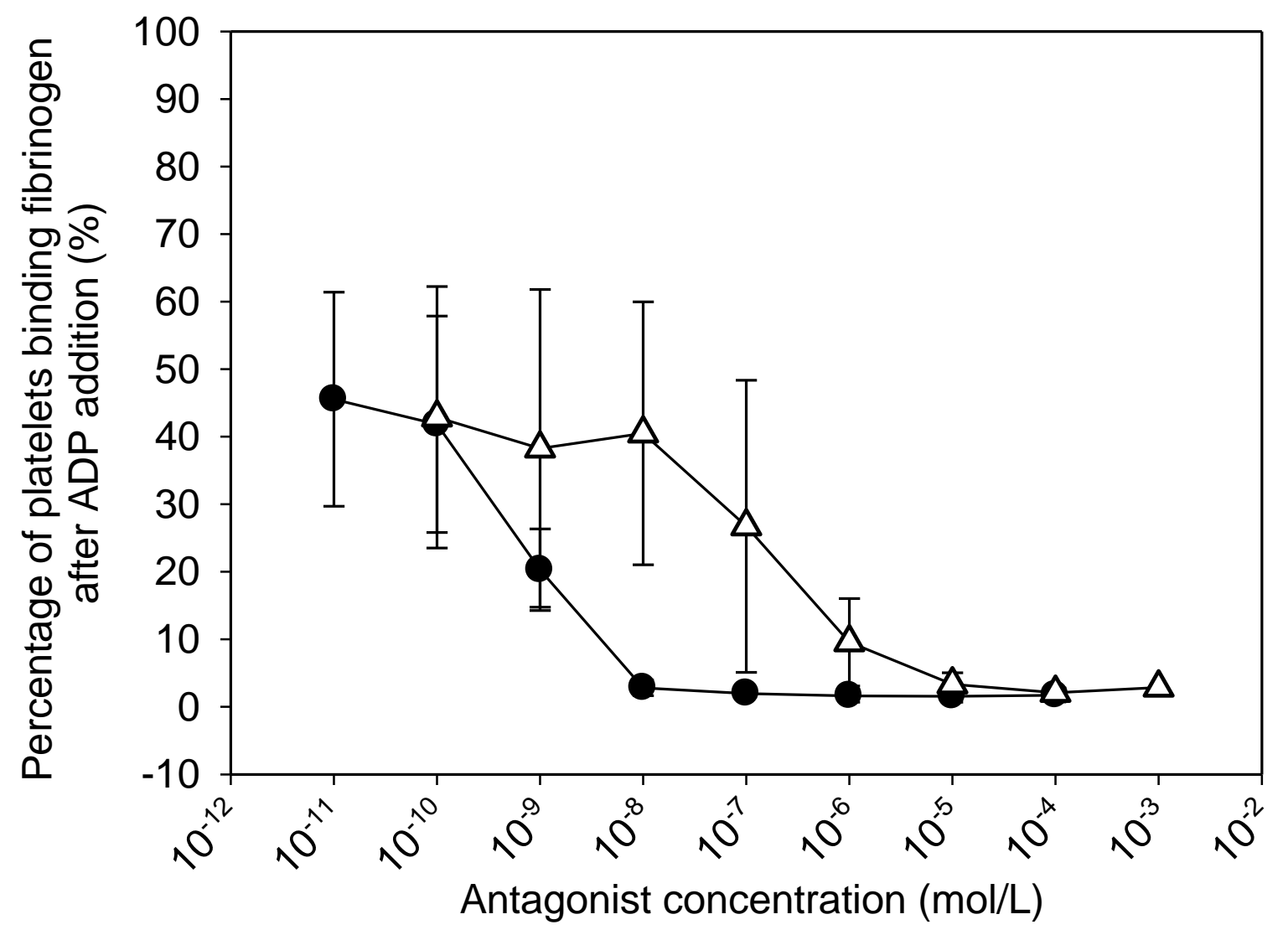

- - AR-C69931MX

$\triangle$ MRS2179 
Figure 4:
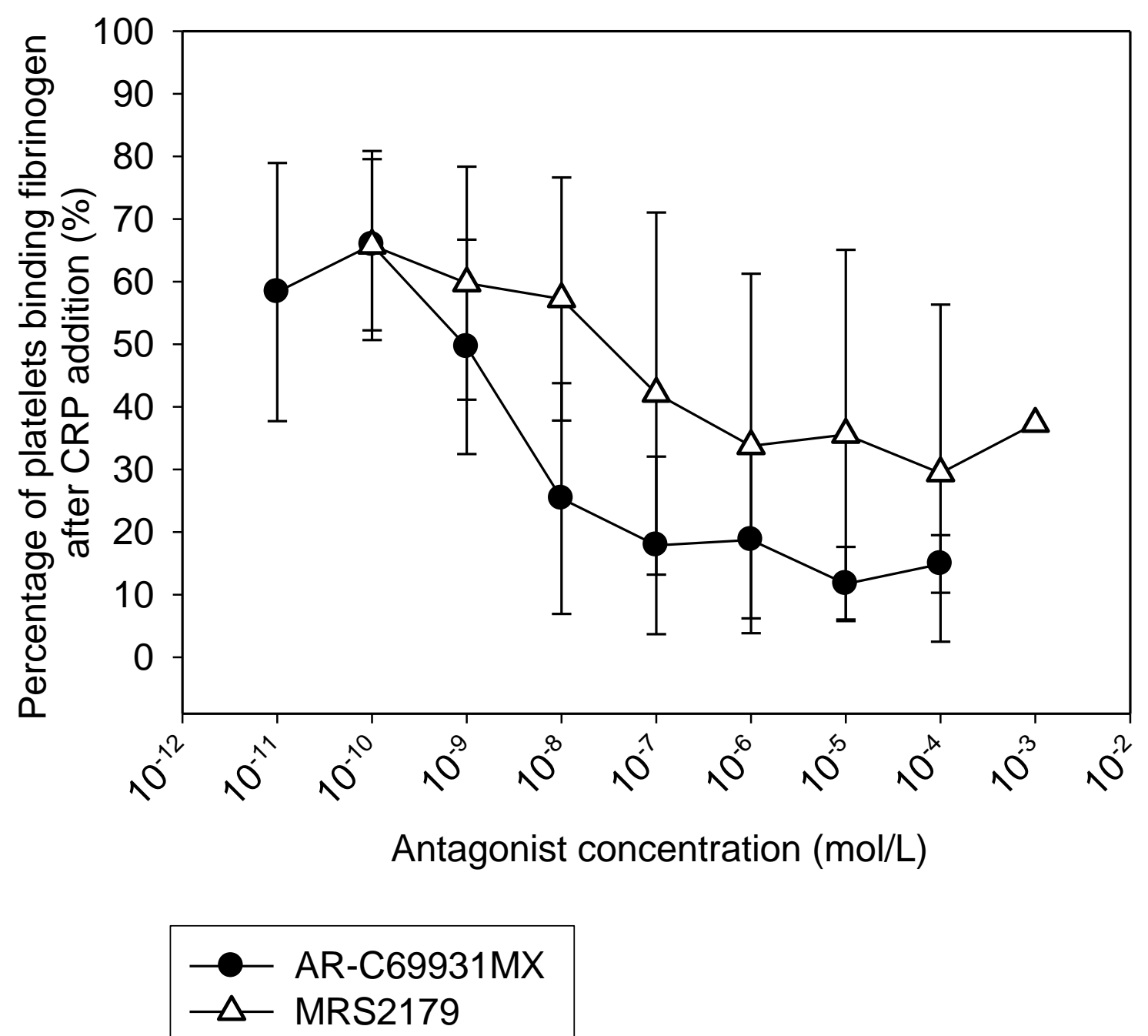
Figure 5:
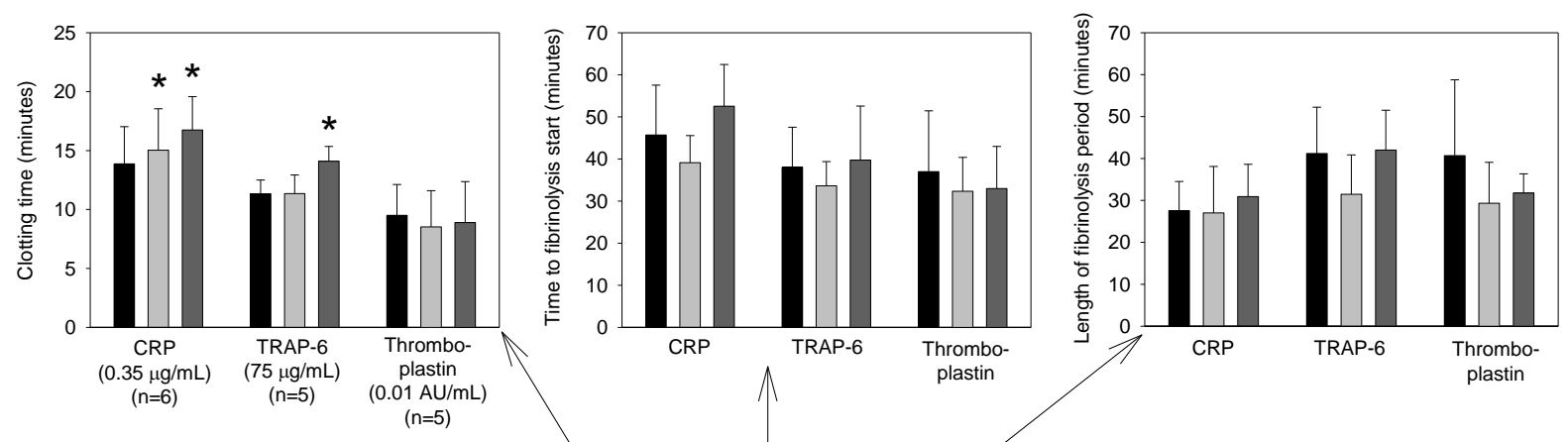

Agonist only Agonist + MRS2179 $(0.2 \mathrm{mmol} / \mathrm{L})$ Agonist + AR-C69931MX (0.1 $\mathrm{mmol} / \mathrm{L})$

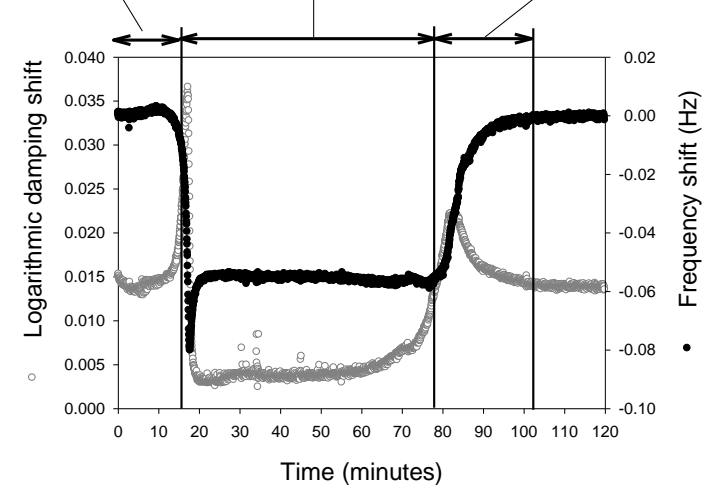


Figure 6:

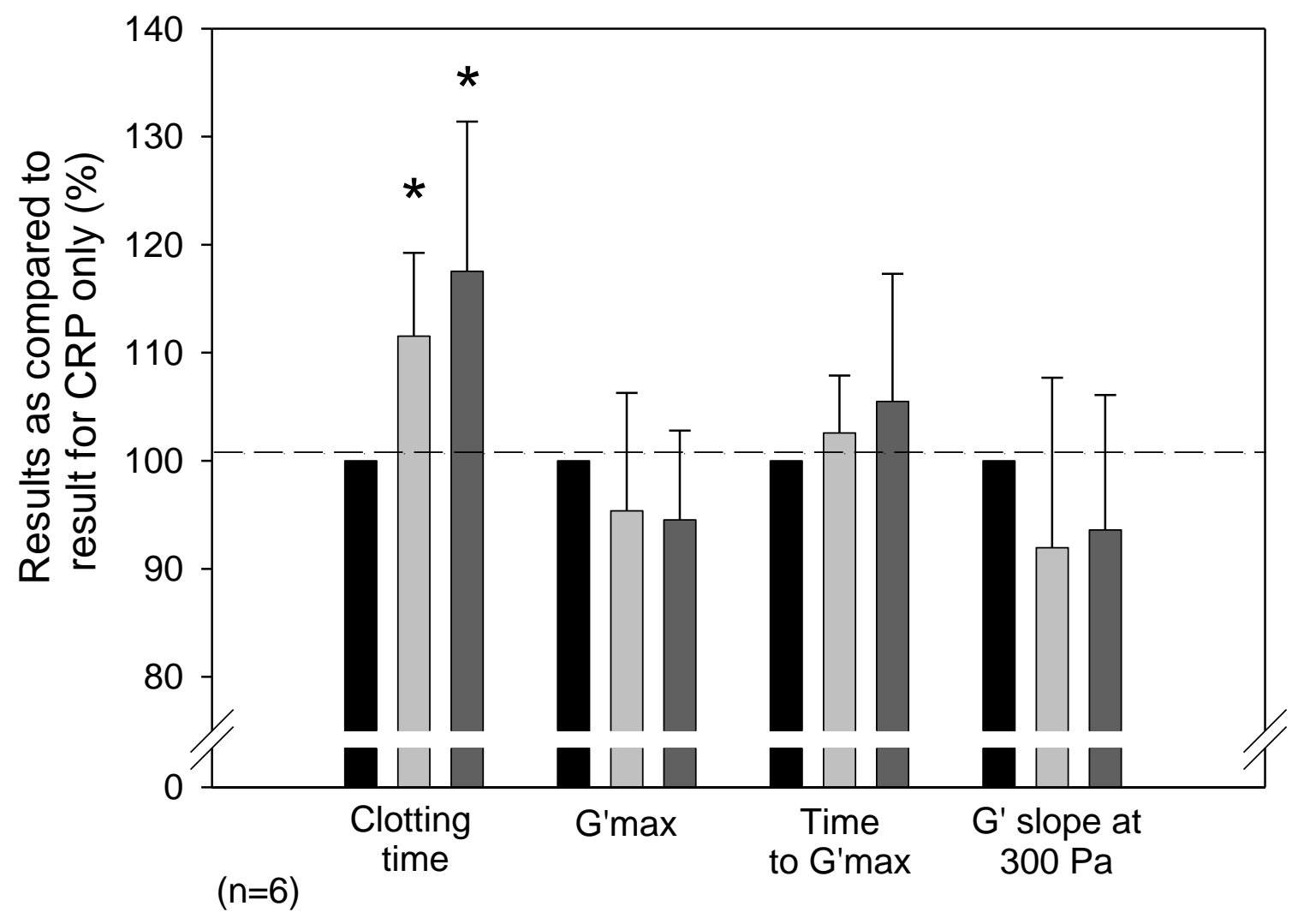

$$
\begin{aligned}
& \text { CRP only }(0.35 \mu \mathrm{g} / \mathrm{mL}) \\
& \text { CRP + MRS2179 }(0.2 \mathrm{mmol} / \mathrm{L}) \\
& \text { CRP + AR-C69931MX }(0.1 \mathrm{mmol} / \mathrm{L})
\end{aligned}
$$

